\title{
Systematic implications from a robust phylogenetic reconstruction of the genus Helianthemum (Cistaceae) based on genotyping-by- sequencing (GBS) data
}

\author{
Sara MARTÍN-HERNANZ ${ }^{1}$, Mauricio VELAYOS ${ }^{2}$, Rafael G. ALBALADEJO ${ }^{3}$, Abelardo APARICIO ${ }^{4 *}$ \\ ${ }^{1,3,4}$ Departamento de Biología Vegetal y Ecología, Universidad de Sevilla, calle Profesor \\ García González 2, 41012 Sevilla, España \\ ${ }^{1,2}$ Real Jardín Botánico, CSIC, Plaza de Murillo 2, 28014 Madrid, España \\ "Correspondence: abelardo@us.es \\ ${ }^{1} \mathrm{https} / / /$ orcid.org/0000-0001-9881-9919, ${ }^{2}$ https://orcid.org/0000-0002-0919-3545 \\ ${ }^{3} \mathrm{https}: / /$ orcid.org/0000-0003-2101-5204, ${ }^{4}$ https://orcid.org/0000-0001-7122-4421
}

\begin{abstract}
Molecular systematics requires the establishment of a robust phylogenetic framework including extensive geographical and taxonomic sampling. In this work, we proposed systematic changes in the genus Helianthemum based on phylogenetic trees obtained by both maximum likelihood and Bayesian analyses of GBS data. The implications of these phylogenetic results for the systematics of Helianthemum entail the establishment of a new subgenus and novel re-ascriptions of sections and species along with some nomenclatural novelties. The following new combinations are proposed: Helianthemum subg. Eriocarpum (Dunal) Martín-Hernanz, Velayos, Albaladejo \& Aparicio; H. oelandicum subsp. conquense (Borja \& Rivas Goday ex G.López) Martín-Hernanz, Velayos, Albaladejo \& Aparicio; H. nummularium subsp. cantabricum (M.Laínz) Martín-Hernanz, Velayos, Albaladejo \& Aparicio; H. nummularium subsp. tinetense (M.Mayor \& Fern.Benito) Martín-Hernanz, Velayos, Albaladejo \& Aparicio.
\end{abstract}

Keywords. Cistaceae, molecular systematics, Next Generation Sequencing.
Resumen. La sistemática molecular requiere un marco filogenético robusto, que incluya un alto porcentaje de los taxones del grupo de estudio y una amplia representación geográfica. En este trabajo presentamos cambios en el género Helianthemum derivados de reconstrucciones filogenéticas con datos tipo GBS analizados tanto con métodos bayesianos como de máxima verosimilitud. Los resultados filogenéticos apoyan la descripción de un nuevo subgénero dentro de Helianthemum, así como la readscripción de taxones a diferentes niveles taxonómicos y algunas novedades nomenclaturales. Se proponen las siguientes combinaciones: Helianthemum subg. Eriocarpum (Dunal) Martín-Hernanz, Velayos, Albaladejo \& Aparicio; H. oelandicum subsp. conquense (Borja \& Rivas Goday ex G.López) Martín-Hernanz, Velayos, Albaladejo \& Aparicio; $H$. nummularium subsp. cantabricum (M.Laínz) Martín-Hernanz, Velayos, Albaladejo \& Aparicio; H. nummularium subsp. tinetense (M.Mayor \& Fern.Benito) Martín-Hernanz, Velayos, Albaladejo \& Aparicio.

Palabras clave. Cistaceae, secuenciación masiva, sistemática molecular.

How to cite this article: Martín-Hernanz S., Velayos M., Albaladejo R.G., Aparicio A. 2021. Systematic implications from a robust phylogenetic reconstruction of the genus Helianthemum (Cistaceae) based on genotyping-by-sequencing (GBS) data. Anales del Jardín Botánico de Madrid 78: e113. https://doi.org/10.3989/ajbm.2601

Title in Spanish: Implicaciones sistemáticas de una reconstrucción filogenética del género Helianthemum (Cistaceae) basada en datos de GBS.

Associate Editor: Ana Ortega. Received: 11 May 2021; accepted: 1 July 2021; published online: 04 Noviembre 2021.

\section{INTRODUCTION}

Molecular systematics requires the establishment of a robust phylogenetic framework, including extensive geographical and taxonomic representativeness, well-supported species relationships and high certainty of tree topology. Particularly, for recently diversified lineages, data from Sanger sequencing-based techniques usually provide very low support due to insufficient DNA variability (DeFilippis \& Moore 2000). Alternatively, reduced-representation sequencing methods such as genotyping-by-sequencing (GBS; Elshire \& al. 2011) have been revealed to be highly resolutive because they allow the discovery of thousands of loci even from non-model species (Fernández-Mazue$\cos \&$ al. 2018).

Under this perspective, the Palearctic genus Helianthemum Mill. (Cistaceae Juss.), whose rapid diversification has been driven by the geo-climatic events that impacted the Mediterranean Basin since the Upper Miocene (see Thompson 2020), is a challenging case of study due to its complex taxonomy and broad geographical distribution 
(Janchen 1925; Quézel \& Santa 1962; Proctor \& Heywood 1968; Greuter \& al. 1984; López-González 1992; Raynaud 1999). To date, two comprehensive molecular phylogenetic reconstructions of the genus Helianthemum have been attempted, one based on the analyses of nrDNA (ITS) plus

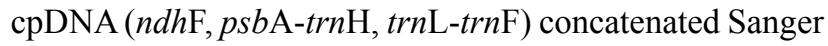
sequences (Aparicio \& al. 2017), the other based on GBS data (Martín-Hernanz \& al. 2019a). Previous phylogenetic analyses based on Sanger sequencing (Aparicio \& al. 2017) provided strong evidence for the generic boundaries in the family Cistaceae as stated by Janchen (1925), i.e., with Crocanthemum Spach restricted to America and Helianthemum to the Old World (also ruling out the segregation of $H$. subg. Plectolobum Willk. into the separate genus Rhodax Spach). Aparicio \& al. (2017) also showed the monophyly of Helianthemum, so defined, and that this genus was integrated by three clades (I, II and III) with no species occupying an early diverging, isolated or intermediate position in relation to the rest of the species. Overall, this study provided support for the above-species classification of the genus, but it was unable to resolve most phylogenetic relationships since most species and subspecies were retrieved in polytomies.

Conversely, the phylogenetic analyses of GBS data (Martín-Hernanz \& al. 2019a) (i) provided highly resolved phylogenetic trees with very strong support even at the most external nodes, (ii) robustly confirmed the three clades previously identified by Aparicio \& al. (2017), and (iii) showed striking similar topologies among them, each one consisting of one species-rich subclade that corresponded with one of the three largest sections in the genus (H. sects. Eriocarpum Dunal, Pseudocistus Dunal and Helianthemum) plus a few very poorly diversified ones: H. sects. Argyrolepis Spach, Lavandulaceum G.López and Pseudomacularia Grosser in clade I; Caput-felis G.López, Macularia Dunal and Atlanthemum (Raynaud) G.López, Ortega Oliv. \& Romero García in clade II; and Brachypetalum Dunal in clade III. On the one hand, this phylogenetic hypothesis (Martín-Hernanz \& al. 2019a) allowed the reconstruction of the biogeographic history of Helianthemum showing that the three largest taxonomic sections represent three evolutionary radiations which synchronously diversified during the Pliocene and Pleistocene, and that clades I, II and III diverged under pre-Mediterranean environmental conditions in northern Africa during the Middle Miocene. Then, clade II expanded throughout arid and semiarid ecosystems in northern Africa, Middle East and central Asia (to a considerably lesser extent to Macaronesia) whereas clades I and III expanded to Mediterranean and temperate regions through much of the Mediterranean Basin, central and northern Europe and the Canary Islands (Martín-Hernanz \& al. 2019a; 2021).
On the other hand, the resulting non-monophyletic taxa advised further systematic changes at different taxonomic ranks. For example, at subgenus level, $H$. subg. Helianthemum as usually considered by taxonomists (i.e., clade II plus clade III) (Spach 1836; Willkomm 1856; Grosser 1903; Janchen 1925; Quézel \& Santa 1962; Proctor \& Heywood 1968; López-González 1992) was retrieved as a non-monophyletic (paraphyletic) group since clade III (H. sects. Brachypetalum and Helianthemum) and clade I (H. subg. Plectolobum) shared a recent-most common ancestor compared to clade II (see Fig. 1A). At the species level, the most common and taxonomically complex species, such as $H$. apenninum (L.) Mill., H. cinereum (Cav.) Pers., H. marifolium (L.) Mill., H. nummularium (L.) Mill. or H. oelandicum (L.) Dum. Cours. were also retrieved as non-monophyletic groups. These are young species probably impacted by the Pleistocene glacial cycles, whose ample variability is usually described by taxonomists as subspecies arrays or species aggregates (e.g., Janchen 1907; Proctor \& Heywood 1968; Greuter \& al. 1984). The biological and taxonomic complexity of these species is also reflected in the low statistical support retrieved for their intraspecific relationships as well as in the existence of topological incongruences for some nodes of the phylogenetic trees (see Fig. 4 in Martín-Hernanz \& al. 2019a), further revealing that trait convergence, incomplete lineage sorting or hybridization and introgression could be playing an essential role in the differentiation of these lineages (Soubani \& al. 2014a, 2014b; Volkova \& al. 2016). Overall, these findings emphasize that, beyond the systematic implications, studies at microevolutionary scale are necessary to evaluate diversification dynamics in these complexes and to understand why most species of Helianthemum are endemic or have very restricted distribution ranges (Martín-Hernanz \& al. 2019a, 2019b).

In this paper, we update the overall systematic scheme of the genus Helianthemum using a robust molecular phylogenetic framework. To that aim, we considered the intrageneric systematic overview and the set of taxa studied by Aparicio \& al. (2017) and Martín-Hernanz \& al. (2019a) which targeted a broad taxonomic and geographic representation of the genus including two subgenera, ten sections, 73 species and 25 subspecies (i.e., about $75 \%$ of the genus) from the entire geographic distribution range (see Fig. 1 in Aparicio \& al. 2017 and Table S2 in Martín-Hernanz \& al. 2019a). Considering the overall statistical robustness of the phylogenetic relationships retrieved, particularly those based on GBS data, the subsequent systematic arrangements entail the establishment of a new subgenus, novel re-ascriptions of sections and species, and several nomenclatural novelties. We are aware that numerous species and subspecies relationships are still unknown and that many taxonomic and nomenclatural questions remain unresolved. Addressing these would require a microevolutionary approach, with detailed 
population level studies and an increased number of samples per population and taxa.

\section{MATERIAL AND METHODS}

The systematic changes proposed here are based on phylogenetic trees obtained by maximum likelihood (RaxML 7.2.8; Stamatakis 2006) and Bayesian (ExaBayes 1.4.1; Aberer \& al. 2014) analyses of a GBS assembly, applying the MaxResol configuration and the minimum 15\% taxon coverage (Martín-Hernanz \& al. 2019a). Briefly, the MaxResol configuration was defined as the parameter set configuration that provided the highest number of supported nodes in the phylogenetic analyses (both Bayesian and Maximum likelihood) as opposed to the MinError configuration, which was designed to minimizing allele and SNP error rates and provided more accurate branch length estimates in the phylogenetic trees (Martín-Hernanz $\&$ al. 2019a). Hence, MaxResol configuration retrieves trees suited for molecular systematic inferences whereas MinError configuration yields trees adequate for downstream analyses concerning the evolutionary history of the genus (molecular dating, ancestral area reconstructions or diversification rates). Minimum taxon coverage refers to the minimum number of samples at a given locus required to be retained in the final dataset. Details about the implications of parameter configuration for the phylogenetic reconstructions are in Martín-Hernanz \& al. (2019a).

\section{RESULTS AND DISCUSSION}

The 50\% majority-rule consensus tree resulting from the Bayesian inference analysis of GBS data shows that most nodes received high statistical support with full posterior probability $(\mathrm{PP}=1)$ and bootstrap $(\mathrm{BS})$ values higher than $70 \%$ (Fig. 1; see also Fig. S1a in Martín-Hernanz $\&$ al. 2019a for bootstrap values). Thus, this tree provides compelling evidence that the genus Helianthemum is integrated by three main lineages (clades I, II and III). Furthermore, it gives very strong support for the non-monophyletic status of $H$. subg. Helianthemum as traditionally considered: i.e., clades II plus III (Spach 1836; Willkomm 1856; Grosser 1903; Janchen 1925; Quézel \& Santa 1962; Proctor \& Heywood 1968; López-González 1992). Therefore, we are proposing a new subgenus coinciding with clade II, making all three subgenera monophyletic. Thus, H. subg. Eriocarpum (clade II) includes sects. Argyrolepis, Lavandulaceum, Pseudomacularia and Eriocarpum; H. subg. Plectolobum (clade I) contains sects. Caput-felis, Atlanthemum, Macularia and Pseudocistus; and, finally, H. subg. Helianthemum (clade III) is formed by sects. Brachypetalum and Helianthemum. Additional nomenclatural combinations and the re-ascription of taxa to different taxonomic levels are further proposed based on strongly supported phylogenetic relationships.
Helianthemum Mill., Gard. Dict. Abr. ed. 4 (1754). Lectotype: H. nummularium (L.) Mill. (Cistus nummularius L.).

Helianthemum subg. Eriocarpum (Dunal) Martín-Hernanz, Velayos, Albaladejo \& Aparicio, stat. \& comb. nov. [三 Helianthemum sect. Eriocarpum Dunal in DC., Prodr. 1: 273 (1824), basion.].

Helianthemum subg. Eriocarpum is mostly integrated by fruticose deserticolous plants with the upper leaves alternate inhabiting arid and semiarid ecosystems from the Maghreb to the Middle East, the Horn of Africa and Central Asia. Helianthemum subg. Helianthemum and H. subg. Pseudocistus are typical fruticulose or suffruticose plants (rarely therophytic) with all leaves opposite inhabiting Mediterranean and Eurosiberian ecosystems from the Mediterranean Basin to northern Europe.

1. Sect. Argyrolepis Spach, Ann. Sci. Nat. ser. 2 (Bot.) 6: 363 (1836). Type: H. squamatum (L.) Dum.Cours., Bot. Cult. 3: 129 (1802).

Included taxon

H. squamatum (L.) Dum.Cours., Bot. Cult. 3: 129 (1802).

2. Sect. Lavandulaceum G.López, Anales Jard. Bot. Madrid 50(1): 43 (1992) [= Helianthemum sect. Polystachyum Willk., Ic. Descr. Pl. 2: 133 (1862), nom. illeg.]. Lectotype: H. lavandulifolium sensu Willk. [H. syriacum (Jacq.) Dum. Cours.].

Included taxa

H. motae Sánchez-Gómez, J.F.Jiménez \& J.B.Vera, Ann. Bot. Fenn. 48: 50 (2011).

H. syriacum (Jacq.) Dum.Cours., Bot. Cult. 3: 129 (1802) [三 Cistus syriacus Jacq., Icon. Pl. Rar. 1: 10 (1784), basion.; H. lavandulifolium auct.].

3. Sect. Pseudomacularia Grosser, Engler, Pflanzenr. IV, 193: 62 (1903). Lectotype (designated here): H. songaricum Schrenk ex Fisch. \& C.A.Mey., Enum. Pl. Nov. 1: 94 (1841).

Grosser (1903) described this section on page 62 of the Engler's Pflanzenreich. Subsequently, on page 92 the author listed the species included without specifying any of them as type of the section. We choose H. songaricum as lectotype.

A recent Sanger-based phylogenetic reconstruction which included six out of the seven species of Helianthemum endemic from the Horn of Africa (Martín-Hernanz $\&$ al. 2021) retrieved the large $H$. sect. Eriocarpum as non-monophyletic due to the inclusion in the same clade of the species that conform $H$. sect. Pseudomacularia, albeit with low statistical support. This is a remarkable result that would require the re-ascription of $H$. sect. Pseudomacular- 


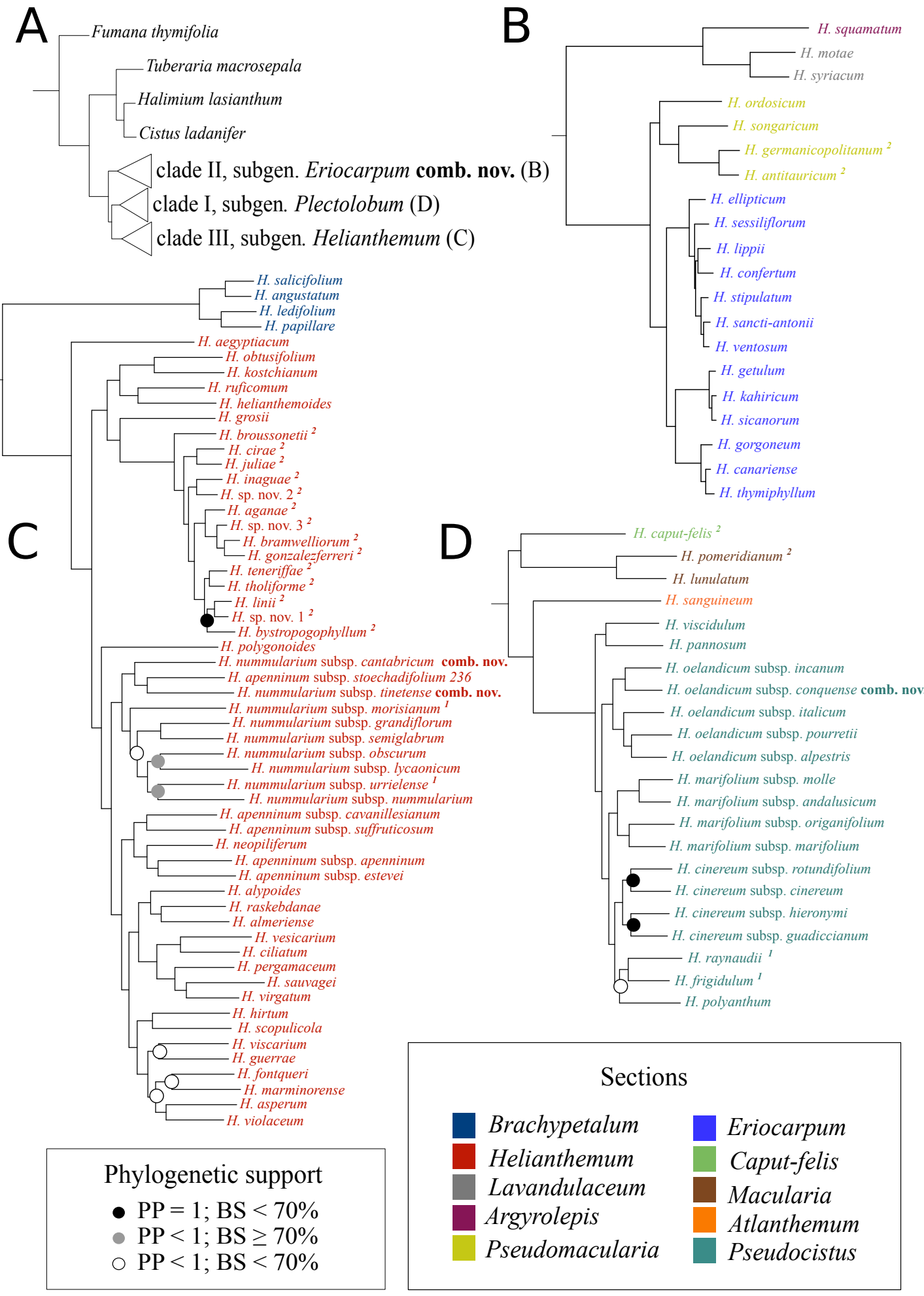

Fig 1. 50\% majority-rule consensus tree resulting from Bayesian analyses of Helianthemum GBS data in ExaBayes using the extreme parameter configuration to maximize phylogenetic resolution (MaxResol) under 15\% minimum taxon coverage (Martín-Hernanz \& al. 2019a): a, Whole phylogenetic tree with the outgroup and the three clades of Helianthemum collapsed for simplicity; b, Subgenus Eriocarpum; $\mathbf{c}$, Subgenus Helianthemum; d, Subgenus Plectolobum. Comb. nov.: newly combined taxa; superscript 1: new taxonomic rank (no new nomenclatural combination required); superscript 2: taxa previously ascribed to a different section or subgenus (see text for details). The original phylogenetic tree was pruned to one tip per taxon following the nomenclature in this paper. Colours indicate the intrageneric assignment of taxa. Unless otherwise stated, the support values for all nodes are posterior Bayesian probability $(\mathrm{PP})=1$ and maximum likelihood bootstrap value $(\mathrm{BS})>70 \%$. 
ia within $H$. sect. Eriocarpum, but at present we keep these two sections as separate entities until the confirmation of this result by means of GBS (i.e., highly resolutive) data, when available. Nevertheless, the GBS-based phylogenetic tree here considered (Martín-Hernanz \& al. 2019a) confirmed the phylogenetic relationship among the Turkey endemics $H$. antitauricum P.H.Davis \& Coode and H. germanicopolitanum Bornm. (which were previously ascribed to sects. Helianthemum and Lavandulaceum, respectively; Aparicio \& al. 2017) and the Asiatic species H. ordosicum Y.Z.Zhao, ZongY.Zhu \& R.Cao and H. songaricum Schrenk ex Fisch. \& C.A.Mey., hence their ascription to $H$. sect. Pseudomacularia.

\section{Included taxa}

H. antitauricum P.H.Davis \& Coode, Notes Roy. Bot. Gard. Edinburgh 26: 201 (1965).

H. germanicopolitanum Bornm., Repert. Spec. Nov. Regni Veg. 27: 352 (1930).

H. ordosicum Y.Z.Zhao, Zong Y.Zhu \& R.Cao, Acta Phytotax. Sin. 38: 294 (2000).

H. songaricum Schrenk ex Fisch. \& C.A.Mey., Enum. Pl. Nov. 1: 94 (1841).

Taxon not included in the phylogenetic analysis

\section{H. strickeri Grosser}

4. Sect. Eriocarpum Dunal in DC., Prodr. 1: 273 (1824). Lectotype (designated here): H. kahiricum Delile, Descr. Egypte, Hist. Nat. 237 (1813).

Dunal (1824) published H. sect. Eriocarpum in De Candolle's Prodromus. After the diagnosis of the new section, the author listed the species included, but did not specify a type of the section. For this reason we selected H. kahiricum as lectotype.

Included taxa

H. argyreum Baker, Bull. Misc. Inform. Kew 1894: 329 (1894).

H. canariense (Jacq.) Pers., Syn. P1. 2: 78 (1806) [三 Cistus canariensis Jacq., Misc. Austriac. 2: 339 (1781), basion.].

H. citrinum Ghaz., Willdenowia 32: 69 (2002).

H. confertum Dunal in DC., Prodr. 1: 274 (1824).

H. cylindrifolium Verdc., Bol. Soc. Brot., sér. 2, 40: 57 (1966).

H. ellipticum (Desf.) Pers., Syn. Pl. 2: 78 (1806).

H. getulum Pomel, Nouv. Mat. Fl. Atl. 2: 353 (1875).

H. gorgoneum Webb, W.J.Hooker, Niger Fl.: 102 (1849).
H. humile Verdc., Bol. Soc. Brot., sér. 2, 40: 59 (1966).

H. kahiricum Delile, Descr. Egypt, Hist. Nat. 237 (1813).

H. lippii (L.) Dum.Cours., Bot. Cult. 3: 130 (1802).

H. sancti-antonii Boiss., Fl. Orient., Suppl.: 70 (1888).

H. sessiliflorum (Desf.) Pers., Syn. Pl. 2: 78 (1806).

H. sicanorum Brullo, Giusso \& Sciandr., Anales Jard. Bot. Madrid 64: 47 (2007).

H. somalense J.B.Gillett, Kew Bull. 9: 493 (1954).

H. speciosum Thulin, Nordic J. Bot. 22: 41 (2002).

H. stipulatum (Forssk.) C.Chr., Dansk Bot. Ark. 4 (3): 20 (1922).

H. thymiphyllum Svent., Addit. Fl. Canar. 1: 35 (1960).

H. ventosum Boiss., Diagn. P1. Orient. 8: 50 (1849).

Taxa not included in the phylogenetic analysis

H. geniorum Maire

H. hadedense Thulin

H. schweinfurthii Grosser

H. sinuspersicum Gholamian \& F.Ghahrem.

The assignation of the endemic species from the Horn of Africa to this section is based on Aparicio \& al. (2017) and Martín-Hernanz \& al. (2021).

Helianthemum subg. Plectolobum Willk., Icon. Descr. Pl. 2: 139 (1862). Rhodax Spach, Ann. Sci. Nat. Bot. Ser. 2, 6: 363 (1836).

1.Sect. Caput-felis G.López, Anales Jard. Bot. Madrid 50(1): 51 (1992). Type: H. caput-felis Boiss., Elench. Pl. Nov.: 16 (1838).

The GBS-based phylogenetic tree provides strong support for the inclusion of $H$. sect. Caput-felis G.López in $H$. subg. Plectolobum. López-González (1992) considered this section to be somewhat intermediate among both subgenera but ascribed it to $H$. subg. Helianthemum despite emphasizing the Plectolobum-like seed morphology of H. caput-felis.

Included taxon

H. caput-felis Boiss., Elench. Pl. Nov.: 16 (1838).

2. Sect. Macularia Dunal in DC., Prodr. 1: 271 (1824). Lectotype (designated here): H. lunulatum (All.) DC. in Lam. \& DC., Fl. Franc. ed 3, 4: 816 (1805).

Dunal (1824) described this section in De Candolle's Prodromus. After the diagnosis of the section, that author did not specify the type of the section. We choose H. lunulatum as lectotype. Helianthemum lunulatum is 
a species restricted to high-altitude ecosystems in the Maritime Alps and the only species usually ascribed to H. sect. Macularia (e.g., Grosser 1903; Janchen 1925; Proctor \& Heywood 1968). However, the analyses retrieved an unexpected sister-relationship among this species and $H$. pomeridianum Dunal (formerly ascribed either to $H$. sect. Eriocarpum or to $H$. sect. Chamaecistus Willk. in different subgenera; Aparicio \& al. 2017), a species restricted to northern Algeria and the Moroccan Atlas Mountains range. This relationship reveals a major intercontinental disjunction happened during the early diversification of $H$. subg. Plectolobum in the Upper Pliocene (Aparicio \& Albaladejo 2017).

\section{Included taxa}

H. lunulatum (All.) DC. in Lam. \& DC., Fl. Franç., ed. 3, 4: 816 (1805) [三 Cistus lunulatus All., Auct. F1. Pedem.: 30 (1789), basion.].

H. pomeridianum Dunal, Mém. Sect. Sci. Acad. Sci. Montpellier 1: 6 (1847) [=H. mathezii Dobignard, J. Bot. Soc. Bot. France 48: 17 (2009).

Taxon not included in the phylogenetic analysis

$$
\text { H. petiolatum Thibaud ex Pers. }
$$

3. Sect. Atlanthemum (Raynaud) G.López, Ortega Oliv. \& Romero García, Anales Jard. Bot. Madrid 50(1): 61 (1992) [三 Atlanthemum Raynaud, Anales Jard. Bot. Madrid 44: 315 (1987), basion.]. Type: A. sanguineum (Lag.) Raynaud [H. sanguineum (Lag.) Lag. ex Dunal in DC., Prodr. 1: 273 (1824).

Similarly, the phylogenetic reconstructions considered in this paper provide strong support for the inclusion of $H$. sanguineum (Lag.) Lag. in the monotypic $H$. sect. Atlanthemum as proposed by López-González (1992), ruling out the consideration of the separate genus Atlanthemum Raynaud (Raynaud 1987).

Included taxon

H. sanguineum (Lag.) Lag. ex Dunal in DC., Prodr. 1: 273 (1824).

4. Sect. Pseudocistus Dunal in DC., Prodr. 1: 275 (1824). Lectotype: H. oelandicum (L.) Dum.Cours. [Cistus oelandicus L.].

Some complex species in this section as currently defined have been retrieved non-monophyletic. The GBS data provide support for the consideration of $H$. frigidulum Cuatrec. and $H$. raynaudii Ortega Oliv., Romero García \& C. Morales at species level, as originally described, i.e., not subordinated either to $H$. marifolium or to $H$. viscidulum Boiss., respectively. Conversely, the con- sideration of $H$. marifolium and $H$. origanifolium (Lam.) Pers. as different species (e.g., Guinea 1954; Proctor \& Heywood 1968; Greuter \& al. 1984; Crespo \& al. 2016) resulted firmly unsupported. Helianthemum oelandicum is an extremely polymorphic complex usually considered as a species' aggregate (Janchen 1907; Yuzepchuk 1974; Tzvelev 2006; Soubani 2010); very interestingly, to this complex is to be ascribed a gypsophile specialist plant endemic to central Spain which was subordinated to H. marifolium (H. marifolium subsp. conquense Borja \& Rivas Goday ex G.López) albeit its morphological relationship with $H$. oelandicum was originally suspected (López-González 1992). For a comprehensive insight of the polymorphic species $H$. cinereum, $H$. marifolium and $H$. polyanthum (Desf.) Pers., it is a requisite to take into account the ample variability that exists at both sides of the strait of Gibraltar.

Included taxa

H. cinereum (Cav.) Pers., Syn. Pl. 2: 76 (1806) subsp. cinereum

H. cinereum subsp. guadiccianum (Font Quer \& Rothm.) G.López, Anales Jard. Bot. Madrid 50(1): 59 (1992) [=H. rossmaessleri Willk., Linnaea 30: 87 (1859)].

H. cinereum subsp. hieronymi (Sennen) G.López, Anales Jard. Bot. Madrid 50(1): 60 (1992).

H. cinereum subsp. rotundifolium (Dunal) Greuter \& Burdet, Willdenowia 11: 275 (1981).

H. frigidulum Cuatrec., Trab. Mus. Ci. Nat. Barcelona 12: 361 (1929) [= H. marifolium subsp. frigidulum (Cuatrec.) G.López, Anales Jard. Bot. Madrid 50(1): 56 (1992)].

H. marifolium (L.) Mill., Gard. Dict. ed. 8, n. ${ }^{\circ} 24$ (1768) subsp. marifolium

H. marifolium subsp. andalusicum (Font Quer \& Rothm.) G.López, Anales Jard. Bot. Madrid 50(1): 54 (1992).

H. marifolium subsp. molle (Cav.) G.López, Anales Jard. Bot. Madrid 50(1): 55 (1992).

H. marifolium subsp. origanifolium (Lam.) G.López, Anales Jard. Bot. Madrid 50(1): 54 (1992) [三 H. origanifolium (Lam.) Pers., Syn. P1. 2: 76 (1806); 三 Cistus origanifolius Lam., Encycl. 2: 21 (1786), basion.].

H. oelandicum (L.) Dum.Cours., Bot. Cult. 3: 129 (1802) subsp. oelandicum

H. oelandicum subsp. alpestre (Jacq.) Ces., Cattaneo, Not. Nat. Civ. Lomb. 1: 288 (1844). 
H. oelandicum subsp. conquense (Borja \& Rivas Goday ex G.López) Martín-Hernanz, Velayos, Albaladejo \& Aparicio, comb. nov. [ $\equiv$ H. marifolium subsp. conquense Borja \& Rivas Goday ex G.López, Anales Jard. Bot. Madrid 50: 55 (1992), basion.; $\equiv H$. conquense (Borja \& Rivas Goday ex G.López) Mateo \& Arán, Flora Montiberica 3: 95 (1996)].

H. oelandicum subsp. incanum (Willk.) G.López, Anales Jard. Bot. Madrid 50(1): 52 (1992).

H. oelandicum subsp. italicum (L.) Ces., Cattaneo, Not. Nat. Civ. Lomb. 1: 288 (1844).

H. oelandicum subsp. pourretii (Timb.-Lagr.) Greuter \& Burdet, Willdenowia 11(2): 276 (1981).

H. pannosum Boiss., Elench. Pl. Nov. 15 (1838).

H. polyanthum (Desf.) Pers., Syn. Pl. 2: 78 (1806).

H. raynaudii Ortega Oliv., Romero García \& C.Morales, Candollea 44(1): 233 (1989) $\equiv H$. viscidulum subsp. raynaudii (Ortega Oliv., Romero García \& C.Morales) G.López, Anales Jard. Bot. Madrid 50(1): 60 (1992)].

H. viscidulum Boiss., Elench. Pl. Nov. (1838).

Taxa not included in the phylogenetic analysis

H. baschkirorum (Juz. ex Kupat.) Juz.

H. buschii (Palib.) Juz. \& Pozdeeva

H. ciscaucasicum Juz. \& Pozdeeva

H. cretaceum Juz. ex Dobrocz.

H. creticola Klokov \& Dobrocz.

H. cretophilum Klokov \& Dobrocz.

H. canum auct.

H. hymettium Boiss. \& Heldr.

H. marmoreum Stevan., Matevski \& Kit Tan

H. oelandicum subsp. rupifragum (A.Kern.) Breistr.

H. pinegense Juz.

H. zheguliense Juz. ex Tzvelev

\section{Helianthemum subg. Helianthemum}

1. Sect. Brachypetalum Dunal, DC., Prodr. 1: 271 (1824). Lectotype: H. ledifolium (L.) Mill.

Included taxa

H. angustatum Pomel, Nouv. Mat. Fl. Atl. 1: 218 (1874).

H. ledifolium (L.) Mill., Gard. Dict. ed. 8: n. ${ }^{o} 20$ (1768).

H. papillare Boiss., Voy. Bot. Espagne: 63 (1839).
H. salicifolium (L.) Mill., Gard. Dict. ed. 8: n. 21 (1768).

Taxon not included in the phylogenetic analysis

H. assadii F. Ghahrem. \& Gholamian

\section{Sect. Helianthemum}

The complex species $H$. apenninum and $H$. nummularium, as currently delimited, have been retrieved as non-monophyletic making necessary some nomenclatural combinations and taxonomic re-ascriptions. Future studies are required to evaluate the variability of $H$. apenninum and to ascertain its relationships with $H$. croceum (Desf.) Pers. (see López-González 1992) and H. neopiliferum Muñoz Garm. \& C. Navarro. On the other hand, a huge ecological and morphological variation is inherent to $H$. nummularium (Proctor \& Heywood 1968; Volkova \& al. 2016) and the results that we analyse in this paper increase the complexity of this taxon. For example, we have unexpectedly found that the sample identified in the phylogenetic tree as $H$. apenninum subsp. stoechadifolium 236, which represents a few populations restricted to maritime sandy soils around the Doñana National Park in the coast of southern Spain (see Table S2 in Martín-Hernanz \& al. 2019a and Fig. 1), clustered within the clade of H. nummularium. Although these plants can be readily identified as $H$. apenninum subsp. stoechadifolium (Brot.) Samp., the facts that this taxon is not cited for this geographic area by López-González (1993) in Flora iberica and the retrieved phylogenetic relationship, stress that a detailed study is necessary to ascertain the real taxonomic identity of these populations. Similarly, the stenochorous $H$. apenninum subsp. urrielense (M.Laínz) G.López and $H$. apenninum subsp. cantabricum (M.Laínz) G.López were retrieved within the clade of $H$. nummularium together with $H$. morisianum Bertol., an endemic taxon from Sardinia, which was previously considered either included in H. nummularium subsp. berteroanum (Bertol.) Breistr. (Pignatti 1982) or as H. nummularium subsp. morisianum (Bertol.) Zangh. (Greuter \& al. 1984).

Also, in this section a cluster of species whose relationships are not fully supported is retrieved [H. guerrae Sánchez-Gómez, J.S.Carrion \& M.A.Carrión, H. viscarium Boiss. \& Reut., H. violaceum (Cav.) Pers., H. asperum Lag. ex Dunal, H. marminorense Alcaraz, Peinado \& Mart.Parras and $H$. fontqueri Sennen plus $H$. hirtum (L.) Mill. and H. scopulicola L.Sáez, Rosselló \& Alomar]. Indeed, this is an extremely complex group of species almost restricted to eastern and southern Spain where phenotypic plasticity and hybridization is very common (e.g., Mateo Sanz 2012; Pérez Da Costa \& Mateo Sanz 2012). Again, the study of this complex of species would require a population level approach with an enlarged number of samples per population and species. This last consideration can be extended to 
the lineage integrated by species mostly from south-eastern Spain and northern Maghreb such as $H$. almeriense Pau, $H$. alypoides Losa \& Rivas Goday, H. virgatum (Desf.) Pers., $H$. pergamaceum Pomel, $H$. ciliatum (Desf.) Pers. and $H$. vesicarium Boiss. where hybridization is also common and the species limit result many times unclear (Quézel \& Santa, 1962; Raynaud 1999). Finally, the analysed GBS data firmly support the existence of the 'Canary Island clade', a monophyletic lineage endemic to the Canary Islands explosively diversified during the Pleistocene (Albaladejo \& al. 2021) whose species were previously ascribed to $H$. sects. Argyrolepis or Lavandulaceum (Aparicio \& al. 2017).

Included taxa

H. aegyptiacum (L.) Mill., Gard. Dict. ed. 8: n. ${ }^{\circ} 23$ (1768).

H. aganae Marrero Rodr. \& R.Mesa, Candollea 58: 154 (2003).

H. aguloi Marrero Rodr. \& R.Mesa, Candollea 58: 151 (2003). [The inclusion is based on Albaladejo \& al. (2021)].

H. almeriense Pau, Mem. Mus. Ci. Nat. Barcelona, Sèr. Bot. 1(3): 11 (1925).

H. alypoides Losa \& Rivas Goday, Anales Inst. Bot. Cavanilles 25: 201 (1968).

H. apenninum (L.) Mill., Gard. Dict. ed. 8 n. ${ }^{\circ} 4$ (1768) subsp. apenninum.

H. apenninum subsp. cavanillesianum (M. Laínz) G.López, Anales Jard. Bot. Madrid 50(1): 48 (1992).

H. apenninum subsp. estevei (Peinado \& Mart. Parras) G.López, Anales Jard. Bot. Madrid 50(1): 49 (1992).

H. apenninum subsp. stoechadifolium (Brot.) Samp., Bol. Soc. Brot., ser. 2, 7: 131 (1931).

H. apenninum subsp. suffruticosum (Boiss.) G.López, Anales Jard. Bot. Madrid 50(1): 49 (1992).

H. asperum Lag. ex Dunal, DC., Prodr. 1: 283 (1824).

H. bramwelliorum Marrero Rodr., Bot. Macaronés., IV, Ci. 19-20: 66 (1992).

H. broussonetii Dunal in DC., Prodr. 1: 279 (1824).

H. bystropogophyllum Svent., Addit. Fl. Canar. 1: 33 (1960).

H. ciliatum (Desf.) Pers., Syn. Pl. 2: 76 (1806).

H. cirae A.Santos, Addit. Fl. Canar. 1: 33 (1960).

H. fontqueri Sennen [= H. abelardoi Alcaraz, Flora Montiber. 60: 140 (2015)].

H. gonzalezferreri Marrero Rodr., Bot. Macaronés., IV, Ci. 19-20: 69 (1992).
H. grosii Pau \& Font Quer, Font Quer, Iter Marocc. 1927: n. ${ }^{\circ} 414$ (1928).

H. guerrae Sánchez-Gómez, J.S.Carrion \& M.A.Carrión, Anales Jard. Bot. Madrid 58: 355 (2000 publ. 2001).

H. helianthemoides (Desf.) Grosser, Engler, Pflanzenr. IV, 193: 87 (1903) [= H. fontanesii Boiss. \& Reut., Pugill. Pl. Afr. Bor. Hispan.: 15 (1852)].

H. hirtum (L.) Mill., Gard. Dict. ed. 8: n. ${ }^{o} 14$ (1768).

H. inaguae Marrero Rodr., Gonz.-Mart. \& F.González, Bot. Macaronés., IV, Ci. 22: 4 (1995).

H. juliae Wildpret, Vieraea 16: 361 (1986).

H. kotschyanum Boiss., Diagn. Pl. Orient., ser. 2, 1: 53 (1854).

H. linii A.Santos, Vieraea 42: 300 (2014).

H. marminorense Alcaraz, Peinado \& Mart.Parras, Veg. Southeastern Spain: 373 (1992).

H. neopiliferum Muñoz Garm. \& C.Navarro, Fl. Iber. 3: 372 (1993).

H. nummularium (L.) Mill., Gard. Dict., ed. 8, n. ${ }^{\circ} 12$ (1768) subsp. nummularium

H. nummularium subsp. cantabricum (M.Laínz) MartínHernanz, Velayos, Albadalejo \& Aparicio, comb. nov. [ $\equiv$ H. croceum subsp. cantabricum M.Laínz, Bol. Inst. Estud. Asturianos, Supl. Ci. 10: 190 (1964), basion.; = H. apenninum subsp. cantabricum (M.Laínz) G.López, Anales Jard. Bot. Madrid 50(1): 49 (1992)].

H. nummularium subsp. grandiflorum (Scop.) Schinz \& Thell. in Schinz \& R.Keller, Fl. Schweiz ed. 3, 2: 249 (1914).

H. nummularium subsp. lycaonicum Coode \& Cullen, Notes Roy. Bot. Gard. Edinburgh 26: 200 (1965).

H. nummularium subsp. morisianum (Bertol.) Zangh., Fl. Ital. 1: 409 (1976) [三 H. morisianum Bertol., Fl. Ital. 5: 374 (1843)].

H. nummularium subsp. obscurum (Celak.) Holub, Acta Horti Bot. Prag. 1963: 53 (1964).

H. nummularium subsp. semiglabrum (Badaro) M. Proctor, Feddes Repert. 79: 59 (1968).

H. nummularium subsp. tinetense (M.Mayor \& Fern.Benito) Martín-Hernanz, Velayos, Albaladejo \& Aparicio, comb. nov. [ $\equiv H$. tinetense M.Mayor \& Fern.Benito, Fontqueria 48: 90 (1997) [publ. 1998], basion.].

H. nummularium subsp. urrielense M.Laínz, Bol. Inst. Estud. Asturianos, Supl. Ci.15: 20 (1970) [三 H. apenninum subsp. urrielense (M.Laínz) G.López, Anales Jard. Bot. Madrid 50(1): 48 (1992)]. 
H. obtusifolium Dunal in DC., Prodr. 1: 281 (1824).

H. pergamaceum Pomel, Nouv. Mat. F1. Atl. 2: 350 (1875).

H. polygonoides Peinado, Mart. Parras, Alcaraz \& Espuelas, Candollea 42: 361 (1987).

H. raskebdanae M.A.Alonso, M.B.Crespo, Juan \& L.Sáez, Phytotaxa 207: 254 (2015).

H. ruficomum (Viv.) Spreng., Syst. Veg. 2: 589 (1825)

H. sauvagei Raynaud, Anales Jard. Bot. Madrid 37: 475 (1980 publ. 1981).

H. scopulicola L.Sáez, Rosselló \& Alomar, Nordic J. Bot. 19: 414 (1999).

H. teneriffae Coss., Bull. Soc. Bot. France 3: 561 (1856).

H. tholiforme Bramwell, J.Ortega \& B.Navarro, Bot. Macaronés., IV, Ci. 2: 69 (1976 publ. 1977).

H. vesicarium Boiss., Diagn. P1. Orient. 8: 50 (1849).

H. violaceum (Cav.) Pers., Syn. P1. 2: 78 (1806)

H. virgatum (Desf.) Pers., Syn. Pl. 2: 79 (1806).

H. viscarium Boiss. \& Reut., Pugill. P1. Afr. Bor. Hispan.: 14 (1852).

Taxa not included in the phylogenetic analysis

H. apenninum subsp. croceum (Desf.) G.López

H. capralense Pérez Dacosta \& Mateo

H. crassifolium Pers.

H. dagestanicum Rupr.

H. edetanum Mateo, Fabado \& C.Torres

H. jonium Lacaita \& Grosser ex Fiori \& Berg.

H. leptophyllum Dunal

H. maritimum Pomel

H. nummularium subsp. berteroanum (Bertol.) Breistr.

H. dianicum Pérez Dacosta, M.B.Crespo \& Mateo

\section{ACKNOWLEDGEMENTS}

We are indebted to Ginés López-González for helpful insights on this manuscript. This research was funded by grants CGL2014-52459-P and CGL2017-82465-P from the Spanish Ministerio de Economía y Competitividad to AA, and CGL2017-85204-C3-1-P to MV. SM-H was funded by the Spanish Secretaría de Estado de Investigación, Desarrollo e Innovación (FPI fellowship, 2015).

\section{REFERENCES}

Aberer A.J., Kobert K., \& Stamatakis, A. 2014. ExaBayes: massively parallel Bayesian tree inference for the whole-genome era. Molecular Biology and Evolution 31: 2553-2556.

Albaladejo R., Martín-Hernanz S., Reyes-Betancort J.A., Santos-Guerra A., Olangua-Corral M. \& Aparicio A. 2021. Reconstruction of the spatiotemporal diversification and ecological niche evolution of Helianthemum (Cistaceae) in the Canary Islands using genotyping-by-sequencing data. Annals of Botany 127: 597-611.

Aparicio A. \& Albaladejo R.J. 2017. On the identity of Helianthemum mathezii and H. pomeridianum (Cistaceae). Anales del Jardín Botánico de Madrid 74: e060.

Aparicio A., Martín-Hernanz S., Parejo-Farnés C., Arroyo J., Lavergne S., Yesilyurt E.B., Zang M-L., Rubio E. \& Albaladejo R.G. 2017. Phylogenetic reconstruction of the genus Helianthemum (Cistaceae) using plastid and nuclear DNA-sequences: systematic and evolutionary inferences. Taxon 66: 868-885.

Crespo M.B., Alonso M.A., Vicente A. \& Villar, J.L. 2016. A new North African subspecies in the Helianthemum origanifolium aggregate $(H$. subg. Plectolobum, Cistaceae). Phytotaxa 252: 263-272.

DeFilippis V.R. \& Moore W.S. 2000. Resolution of phylogenetic relationships among recently evolved species as a function of amount of DNA sequence: an empirical study based on woodpeckers (Aves: Picidae). Molecular Phylogenetics and Evolution 16: 143-160.

Dunal F. 1824. Cistineae. In Candolle A.P. de (ed.), Prodromus systematis naturalis regni vegetabilis, vol. 1: 263-288. Sumptibus sociorum Treuttel et Würtz, Parisiis [Paris].

Elshire R.J., Glaubitz J.C., Sun Q., Poland J.A., Kawamoto K., Buckler E.S. \& Mitchell S.E. 2011. A robust, simple Genotyping-by-Sequencing (GBS) approach for high diversity species. PLoS One 6: e19379.

Fernández-Mazuecos M., Mellers G., Vigalondo B., Sáez L., Vargas P. \& Glover B.J. 2018. Resolving Recent Plant Radiations: Power and Robustness of Genotyping-by-Sequencing. Systematic Biology 67: 250-268.

Greuter W., Burdet H. \& Long, G. 1984. Med-Checklist. Pteridophyta, Gymnospermae, Dicotyledones (Acanthaceae-Cneoraceae) 1:320-328. Conservatoire et Jardin Botaniques, Genève.

Grosser W. 1903. Cistaceae. In Engler H.G.A. (ed.), Das Pflanzenreich vol. 4. Berlin, Leipzig.

Guinea E. 1954. Cistáceas españolas (con exclusión del género Cistus). Instituto forestal de investigaciones y experiencias, Madrid.

Janchen E. 1907. Helianthemum canum (L.) Baumg. und seine nächsten Verwandten. Abhandlungen der K. K. Zool.-Botan. Gesellschaft in Wien 4: $1-67$.

Janchen E. 1925. Cistaceae. In Engler A. (ed.), Die Natürlichen Pflanzenfamilien, ed. 2, 21: 289-313. Engelmann, Leipzig.

López-González G. 1992. Apuntes para justificar el tratamiento del género Helianthemum Miller, s.l. (Cistaceae), en Flora Iberica. Anales del Jardín Botánico de Madrid 50: 35-63.

López-González G. 1993. Helianthemum Mill. In Castroviejo S., Aedo C., Cirujano S., Laínz M., Montserrat P., Morales R., Muñoz Garmendia F., Navarro C., Paiva J. \& Soriano C. (eds.), Flora iberica 3: 365-421. Real Jardín Botánico, CSIC, Madrid.

Martín-Hernanz S., Albaladejo R.G., Lavergne S., Rubio E., Grall A. \& Aparicio A. 2021. Biogeographic history and environmental niche 
evolution in the Palearctic genus Helianthemum (Cistaceae). Molecular Phylogenetics and Evolution 163: 107238.

Martín-Hernanz S., Aparicio A., Fernández-Mazuecos M., Rubio E., Reyes-Betancort A., Santos-Guerra A., Olangua-Corral M. \& Albaladejo R.G. 2019a. Maximize Resolution or Minimize Error? Using Genotyping-By-Sequencing to Investigate the Recent Diversification of Helianthemum (Cistaceae). Frontiers in Plant Science 10: 1416.

Martín-Hernanz S., Martínez-Sánchez S., Albaladejo R.G., Lorite J., Arroyo J. \& Aparicio A. 2019b. Genetic diversity and differentiation in narrow versus widespread taxa of Helianthemum (Cistaceae) in a hotspot: The role of geographic range, habitat, and reproductive traits. Ecology and Evolution 9: 3016-3029.

Mateo Sanz, G. 2012. Nuevos taxones del género Helianthemum Miller en la zona oriental de la Península Ibérica, I. Flora Montiberica 50: 30-43.

Pérez Da Costa J.M. \& Mateo Sanz G. 2012. Nuevos taxones del género Helianthemum Miller en la zona oriental de la Península Ibérica, II Flora Montiberica 50: 44-61.

Pignatti S. 1982. Flora d'Italia vol. 2. Edagricole, Bologna.

Proctor M. \& Heywood V. 1968. Helianthemum Miller. In Tutin T.G., Heywood V.H., Burges N.A., Moore D.M., Valentine D.H., Walters S.M \& Webb D.A. (eds.), Flora Europaea 2: 286-292. Cambridge University Press, Cambridge.

Quézel P.\& Santa S. 1962. Nouvelleflore de l'Algérie et des régions désertiques méridionales. Centre Nationale de la Recherche Scientifique, Paris.

Raynaud C. 1987. Atlanthemum Raynaud, un nouveau genre pour la famille des Cistaceae. Anales del Jardín Botánico de Madrid 44: 309-317.

Raynaud C. 1999. Cistaceae. In Fennane M., Ibn Tattou M., Mathez J., Aïcha O., El Oualidi, J. (eds.), Flore pratique du Maroc: Manuel de détermination des plantes vasculaires vol. 1. Travaux de l'Institut Scientifique, Université Mohammed V, Série Botanique 36. Rabat: Institut Scientifique Université Mohammed V, Rabat.
Soubani E. 2010. Systematics, phylogeography and multiple origins of morphs in two species complexes belonging to Cistaceae, Helianthemum oelandicum and H. nummularium. Ph.D. dissertation, Lund University, Lund.

Soubani E., Hedrén M. \& Widén B. 2014a. Phylogeography of the European rock rose Helianthemum nummularium (Cistaceae): Incongruent patterns of differentiation in plastid DNA and morphology. Botanical Journal of the Linnean Society 176: 311-331.

Soubani E., Hedrén M. \& Widén B. 2014b. Genetic and morphological differentiation across a contact zone between two postglacial immigration lineages of Helianthemum nummularium (Cistaceae) in southern Scandinavia. Plant Systematics and Evolution 301: 1499-1508.

Spach E. 1836. Conspectus monographiae Cistacearum. Annales des Sciences Naturelles, Botanique, ser. 2, 6: 357-375.

Stamatakis A. 2006. RAxML-VI-HPC: maximum likelihood-based phylogenetic analyses with thousands of taxa and mixed models. Bioinformatics 22: 2688-2690.

Thompson J.D. 2020. Plant Evolution in the Mediterranean. Insights for Conservation. Oxford University Press, Oxford.

Tzvelev, N. 2006. Flora of Russia: The European part and bordering regions vol. 9. CRC Press/Balkema, Rotterdam.

Volkova P.A., Schanzer I.A., Soubani E., Meschersky I.G. \& Widén B. 2016. Phylogeography of the European rock rose Helianthemum nummularium s.l. (Cistaceae): Western richness and eastern poverty. Plant Systematics and Evolution 302: 781-794.

Willkomm M. 1856. Icones et descriptiones plantarum novarum criticarum et rariorum Europae Austro-Occidentalis praecipue Hispaniae vol. 2. Sumtibus A.H. Payne, Leipzig.

Yuzepchuk S.V. 1974. Helianthemum Adans. In Schishkin B.K. (ed.), Flora of the U.S.S.R. 15: 248-260. Trans. from Russian by N. Landau. Israel Program for Scientific Translations, Jerusalem. 